OPEN ACCESS

Edited by:

Thea Magrone

University of Bari, Italy

Reviewed by:

Yaqing Qie,

Mayo Clinic Florida, United States

Per Wändell,

Karolinska Institute (KI), Sweden

*Correspondence:

Marie-Paule Vasson m-paule.vasson@uca.fr

Specialty section

This article was submitted to Nutritional Immunology,

a section of the journal

Frontiers in Immunology

Received: 07 September 2018 Accepted: 11 January 2019 Published: 08 February 2019

Citation:

Goncalves-Mendes N, Talvas J, Dualé C, Guttmann A, Corbin V, Marceau G, Sapin V, Brachet $P$,

Evrard B, Laurichesse $H$ and Vasson M-P (2019) Impact of Vitamin

$D$ Supplementation on Influenza

Vaccine Response and Immune

Functions in Deficient Elderly Persons:

A Randomized Placebo-Controlled

Trial. Front. Immunol. 10:65.

doi: 10.3389/fimmu.2019.00065

\section{Impact of Vitamin D Supplementation on Influenza Vaccine Response and Immune Functions in Deficient Elderly Persons: A Randomized Placebo-Controlled Trial}

\author{
Nicolas Goncalves-Mendes ${ }^{1}$, Jérémie Talvas ${ }^{1}$, Christian Dualé ${ }^{2}$, Aline Guttmann ${ }^{3}$, \\ Violaine Corbin ${ }^{4}$, Geoffroy Marceau ${ }^{5}$, Vincent Sapin ${ }^{5}$, Patrick Brachet ${ }^{1}$, \\ Bertrand Evrard ${ }^{1,6}$, Henri Laurichesse ${ }^{1,4}$ and Marie-Paule Vasson ${ }^{1,7,8 *}$ \\ ${ }^{1}$ University of Clermont Auvergne, INRA, UMR 1019 Human Nutrition Unit, Clermont-Ferrand, France, ${ }^{2} \mathrm{CHU}$ \\ Clermont-Ferrand, INSERM CIC 1405, University of Clermont Auvergne, Clermont-Ferrand, France, ${ }^{3} \mathrm{CHU}$ \\ Clermont-Ferrand, Biostatistics Unit, University of Clermont Auvergne, Clermont-Ferrand, France, ${ }^{4} \mathrm{CHU}$ Clermont-Ferrand, \\ Infectious Diseases Department, University of Clermont Auvergne, Clermont-Ferrand, France, ${ }^{5} \mathrm{CHU}$ Clermont-Ferrand, \\ Biochemistry and Molecular Biology Department, University of Clermont Auvergne, Clermont-Ferrand, France, ${ }^{6} \mathrm{CHU}$ \\ Clermont-Ferrand, Immunology Department, University of Clermont Auvergne, Clermont-Ferrand, France, ${ }^{7} \mathrm{CHU}$ \\ Clermont-Ferrand, Nutrition Unit, University of Clermont Auvergne, Clermont-Ferrand, France, ${ }^{8}$ Centre Jean Perrin, Nutrition \\ Unit, Clermont-Ferrand, France
}

Background: Immunosenescence contributes to reduced vaccine response in elderly persons, and is worsened by deficiencies in nutrients such as Vitamin (Vit-D). The immune system is a well-known target of Vit-D, which can both potentiate the innate immune response and inhibit the adaptive system, and so modulate vaccination response.

Objective: This randomized placebo-controlled double-blind trial investigated whether Vit-D supplementation in deficient elderly persons could improve influenza seroprotection and immune response.

Design: Deficient volunteers (Vit-D serum $<30 \mathrm{ng} / \mathrm{mL}$ ) were assigned (V1) to receive either 100,000 IU/15 days of cholecalciferol ( $D, n=19)$, or a placebo $(\mathrm{P}, n=19)$, over a 3 month period. Influenza vaccination was performed at the end of this period (V2), and the vaccine response was evaluated 28 days later (V3). At each visit, serum cathelicidin, immune response to vaccination, plasma cytokines, lymphocyte phenotyping, and phagocyte ROS production were assessed.

Results: Levels of serum 25-(OH)D increased after supplementation (D group, V1 vs. V2: $20.7 \pm 5.7$ vs. $44.3 \pm 8.6 \mathrm{ng} / \mathrm{mL}, p<0.001)$. No difference was observed for serum cathelicidin levels, antibody titers, and ROS production in D vs. P groups at V3. Lower plasma levels of TNF $\alpha(p=0.040)$ and IL-6 $(p=0.046)$, and higher ones for TFG $\beta(p=$ 0.0028 ) were observed at $\mathrm{V} 3$. The Th1/Th2 ratio was lower in the $\mathrm{D}$ group at V2 (D: 0.12 \pm 0.05 vs. $P: 0.18 \pm 0.05, p=0.039$ )

Conclusions: Vit-D supplementation promotes a higher TGF $\beta$ plasma level in response to influenza vaccination without improving antibody production. This supplementation 
seems to direct the lymphocyte polarization toward a tolerogenic immune response. A deeper characterization of metabolic and molecular pathways of these observations will aid in the understanding of Vit-D's effects on cell-mediated immunity in aging. This clinical trial was registered at clinicaltrials.gov as NCT01893385.

Keywords: vitamin-D deficiency, influenza vaccination, aging, cathelicidin, cytokine, leukocyte phenotyping, randomized trial

\section{INTRODUCTION}

Influenza infection occurs in people of all ages, but complications are more frequent in elderly persons $(1,2)$. This is partly due to immune dysfunctions caused by aging, i.e., immunosenescence, which can be explained by increased antigenic challenges and chronic inflammation, worsened by deficiencies in nutrients such as Vitamin D (Vit-D) (3-5). Vit-D deficiency, defined as 25-hydroxyvitamin D [25-(OH)D] serum levels below $30 \mathrm{ng} / \mathrm{mL}$, is seen in $50-80 \%$ of the French population $(6,7)$. Vit-D deficiency occurs more frequently in older adults than in young ones because of their lower endogenous Vit-D synthesis, and because of their often reduced dietary intake (8).

Recent studies have demonstrated an expression of the Vit-D receptor (VDR) in almost all immune cells, suggesting that Vit$\mathrm{D}$ has anti-infectious and immunomodulatory effects (9). These cells also express $1 \alpha$-hydroxylase CYP27B1, which converts $25-(\mathrm{OH}) \mathrm{D}$ into bioactive $1,25-(\mathrm{OH})_{2} \mathrm{D}(10,11)$. Among the mechanisms contributing to the anti-infectious properties of Vit$\mathrm{D}$, the production of antimicrobial peptides such as cathelicidin (also called LL-37) has been reported (12). Cathelicidin, an antimicrobial polypeptide produced by phagocyte cells, provides protection against bacterial infection. Its expression in respiratory epithelium is upregulated by active metabolites of vitamin D $(12,13)$. Moreover, cathelicidin has direct antiviral effects against influenza $(14,15)$. Tripathi et al. have partially characterized the mechanism of this activity based on the inhibition of viral replication at early stages of intracellular life cycle of the virus $(16,17)$. Recent findings show that cathelicidin is also able to exert immunomodulatory effects via interaction with several receptors such as CXCR4 and induction of signaling pathways (NFkB, MAPK) in immune cells (18). A further antiinfectious property of Vit-D is a result of the activation of the phagocyte NADPH oxidase (NOX), which induces an increase in reactive oxygen species (ROS) production $(19,20)$.

Vit-D is known to shift the T-cell response from a $\mathrm{T}$ helper 1 (Th1) to a Th2-mediated cell response, and thereby reduce inflammation and promote an immunosuppressive state (2123). Moreover, it promotes in vitro the regulatory $\mathrm{T}$ cells (Treg) differentiation via an indoleamine 2,3-dioxygenase (IDO)dependent pathway $(24,25)$. Thus Vit-D may be an important immune response regulator, notably in vaccine and infection challenges $(26,27)$.

The public health strategy for influenza is to reduce severe outcomes such as hospitalization and death by recommending annual vaccinations, particularly for people over 65 years old $(28,29)$. However, the vaccine efficacy is lower for older persons (17-53\%) than for young adults (70-90\%) (30, 31). This could be related to the Vit-D deficiency as reported in previous clinical studies (32-34). To our knowledge, no Vit-D supplementation trial has yet been conducted in Vit-D-deficient elderly populations with the aim of improving vaccination efficacy.

Considering these data, we assessed the impact of VitD supplementation on the immune response to influenza vaccination in Vit-D-deficient elderly volunteers by evaluating (i) cathelicidin status, and (ii) antibody response to vaccine, cytokine production, IDO activity, lymphocyte polarization and ROS production.

\section{MATERIALS AND METHODS}

\section{Volunteer Recruitment and Randomization}

Eligible volunteers were over 65 years old and accepted Vit-D or placebo supplementation and influenza vaccination. Exclusion criteria included prior hypersensitivity to Vit-D (in the previous year), ongoing Vit-D supplementation, previous side effects, and complications after vaccination, hypercalcemia $(>2.6 \mathrm{mmol} / \mathrm{L})$, dysparathyroidism, renal impairment, and long-term treatment with bisphosphonates, corticosteroids, or fibrates.

Volunteers were randomly assigned to blocks of four by sex and age using a computerized random-sequence-generation program run by an independent researcher who was not involved in the data collection, analysis, or reporting. For the supplementation, placebo and Vit-D doses were identical in appearance to maintain blinding, and all participants, investigators, and outcome assessors remained blinded until after all of the data was inputted.

\section{Protocol Design}

This randomized double-blind controlled trial was authorized by the ethics committee (Comite de Protection des Personnes SudEst 6, Clermont-Ferrand, France) and the French state authority (Agence Nationale de Sécurité du Médicament). It was registered on EudraCT under ref. 2012-005658-52 and on clinicaltrials.gov as NCT01893385. At the inclusion visit the volunteers gave fully informed written consent, and then blood samples were taken to determine serum Vit-D levels and the biological parameters required to validate eligibility criteria: blood cell count, and usual plasma and urinary levels of calcium, phosphorus, creatinine, liver enzymes (AST, ALT), glucose, and total proteins. Based on serum Vit-D data, the volunteers were grouped as follows: (i) persons with a serum Vit-D level greater than or equal to 30 $\mathrm{ng} / \mathrm{mL}$ : these individuals were excluded, and advised to accept an influenza vaccine in autumn; (ii) persons with a Vit-D level 
below $30 \mathrm{ng} / \mathrm{mL}$ : these individuals were randomly assigned to one of two groups: (1) a supplemented group (D) receiving six Vit-D doses (Uvedose ${ }^{\circledR}$ 100,000 IU, 1 vial/15 days, Crinex Lab.) over 3 months, followed by an influenza vaccination; (2) a control group $(\mathrm{P})$ receiving a placebo (1 vial/15 days, Crinex Lab.) over 3 months, followed by an influenza vaccination. The participants' compliance was verified by restitution of all empty vials at each visit.

Influenza vaccination was carried out using the IM vaccine Vaxigrip ${ }^{\circledR} \quad$ (Sanofi Pasteur), which provides seroprotection against all seasonal influenza strains, namely A/California/7/2009 (H1N1, pdm09), A/Texas/50/2012 (H3N2), and $\mathrm{B} /$ Massachusetts/2/2012 (Yamagata lineage). The volunteers committed not to change their eating habits, and were assessed at three different stages: at inclusion (V1), after 3 months of supplementation (V2), and 1 month after vaccination (V3). A survey of side effects and complications was performed at each visit and by telephone interview. For the $\mathrm{D}$ group, serum Vit-D concentration, calcemia, and calciuria were monitored after 2 months of supplementation. The biological parameters discussed in the following paragraphs were measured at each visit (V1, V2, and V3).

\section{Serum Vit-D and Cathelicidin Assays}

Serum 25-(OH)D was measured by chemiluminescence immunoassay (Liaison XL analyzer, DiaSorin). Serum cathelicidin (LL-37 protein) was quantified using a doublesandwich ELISA, following the manufacturer's guidelines (Hycult Biotechnology-HK321).

\section{Serum Antibody Quantification}

Vaccine response was assessed at two points (V2 and V3) by measuring hemagglutination inhibition (HAI) antibody (Ab) titers against the influenza vaccine antigens. The HAI test was performed in microplates by incubating serum with the 20132014 influenza reference strains (H1N1, H3N2, and Yamagata), following the WHO procedure. Inter assay quality control was performed with reference antisera as positive controls. Erythrocyte controls allowed adjustments in incubation time and were performed on each plate. Each field isolate antigen and the control antigens have been tested with a negative serum control. The HAI Ab titer was defined as the highest dilution of serum inhibiting the agglutination of guinea pig erythrocytes (Charles River Lab.). In accordance with the European Agency for the Evaluation of Medicinal Products' guidelines (35), data was expressed in 3 ways: geometric mean titer (GMT) with a $95 \%$ confidence interval; seroconversion rate (percentage of subjects achieving at least a 4-fold increase, or an increase from $>10$ to 40 in HAI Ab titer for seronegative subjects); and seroprotection rate, i.e., percentage of subjects reaching an HAI Ab titer 40 .

\section{Plasma Cytokine Assays}

The concentrations of plasma cytokines were quantified using a multiplex assay (Milliplex, Millipore), following the manufacturer's instructions: IL-5, IL-6, IL-10, IL-13, IL-17A, IFN $\gamma$, TNF $\alpha$ (Hcytomag-60K-7plex). For IL-23 and TGF $\beta$, a singleplex assay was used (Tgfbmag-64K-01-1plex).

\section{Serum Tryptophan (Trp) and Kynurenine (Kyn) Assays}

IDO activity was determined for half of the volunteers (P group, $n=10$; D group, $n=9$ ), and estimated by the ratio of Kyn to Trp serum concentrations as described previously (36). Shortly after deproteinization serum samples were analyzed using HPLC on a reverse phase C18 column (Thermo Scientific). Kyn and Trp concentrations $(\mu \mathrm{mol} / \mathrm{L})$ were calculated using the area under the curve method.

\section{Lymphocyte Phenotyping and ROS Production}

Fresh leukocytes were obtained from volunteers' blood samples. After hemolysis, leukocytes were separated on a discontinuous Ficoll-Hypaque density gradient (Histopaque ${ }^{\circledR} 1077$ and 1119; Sigma) as described previously (37). Lymphocyte population was tested for purity $(>95 \%)$ and viability $(>95 \%)$ and phenotyped by flow cytometry (LSRII, BD Biosciences) using antibody panels: anti CD3-VioBlue (T-cell), anti CD4-APC (Th), anti CD25-APC (activated T-cell), anti CD183 (CXCR3)-PE-Vio770 (Th1), anti CD294 (CRTh2)-PE (Th2), anti CD196 (CCR6) PercP-Cy5.5 (Th17, Biolegend, San Diego), and anti CD127FITC (Treg, Myltenyi BioTec, Paris). FACS gating strategy was illustrated in Figure 7A: compensations and controls used the FMO (Fluorescence Minus One) procedure with corresponding antibody isotypes.

ROS production of polymorphonuclear cells (PMN) was quantified from hemolyzed blood by an intracellular fluorescent probe $\left[2^{\prime}, 7^{\prime}\right.$-dichlorofluorescein (DCF) $1 \mu \mathrm{M}$, Sigma-Aldrich] using flow cytometry, as described previously (3).

\section{Sample Size and Study Power}

The primary outcome of the trial was the difference in serum cathelicidin levels between the placebo and Vit-D study arms after 3 months of supplementation. To detect this significant difference, the calculation was based on the hypothesis that the mean \pm SD baseline serum cathelicidin concentration was 13.3 $\pm 1.8 \mathrm{ng} / \mathrm{ml}$ and that the Vit-D supplementation would cause a difference of $1.26 \pm 2.1 \mathrm{ng} / \mathrm{ml}$ in cathelicidin between the 2 arms ( $80 \%$ power with $\alpha=0.05)$. Taking these assumptions into account, we calculated a group size of 42 participants per arm.

\section{Statistical Analysis}

Data are expressed as mean \pm SEM. Statistical analysis was performed using GraphPad Prism ${ }^{\circledR} 5.03$ for Windows (GraphPad Software Inc., San Diego, CA, USA). Vit-D supplementation and period effects were analyzed by twoway ANOVA followed by a Bonferroni post hoc test. Differences within groups were determined by a paired Student $t$-test or a Wilcoxon matched-pairs signed-ranks test. Differences between groups were tested by an independent Student $t$-test or a Mann-Whitney $U$-test. Differences were considered statistically significant at $p<0.05$. The relationship between serum Vit-D and cathelicidin data was assessed using a Pearson correlation (significant threshold: $p<0.05$ ). 


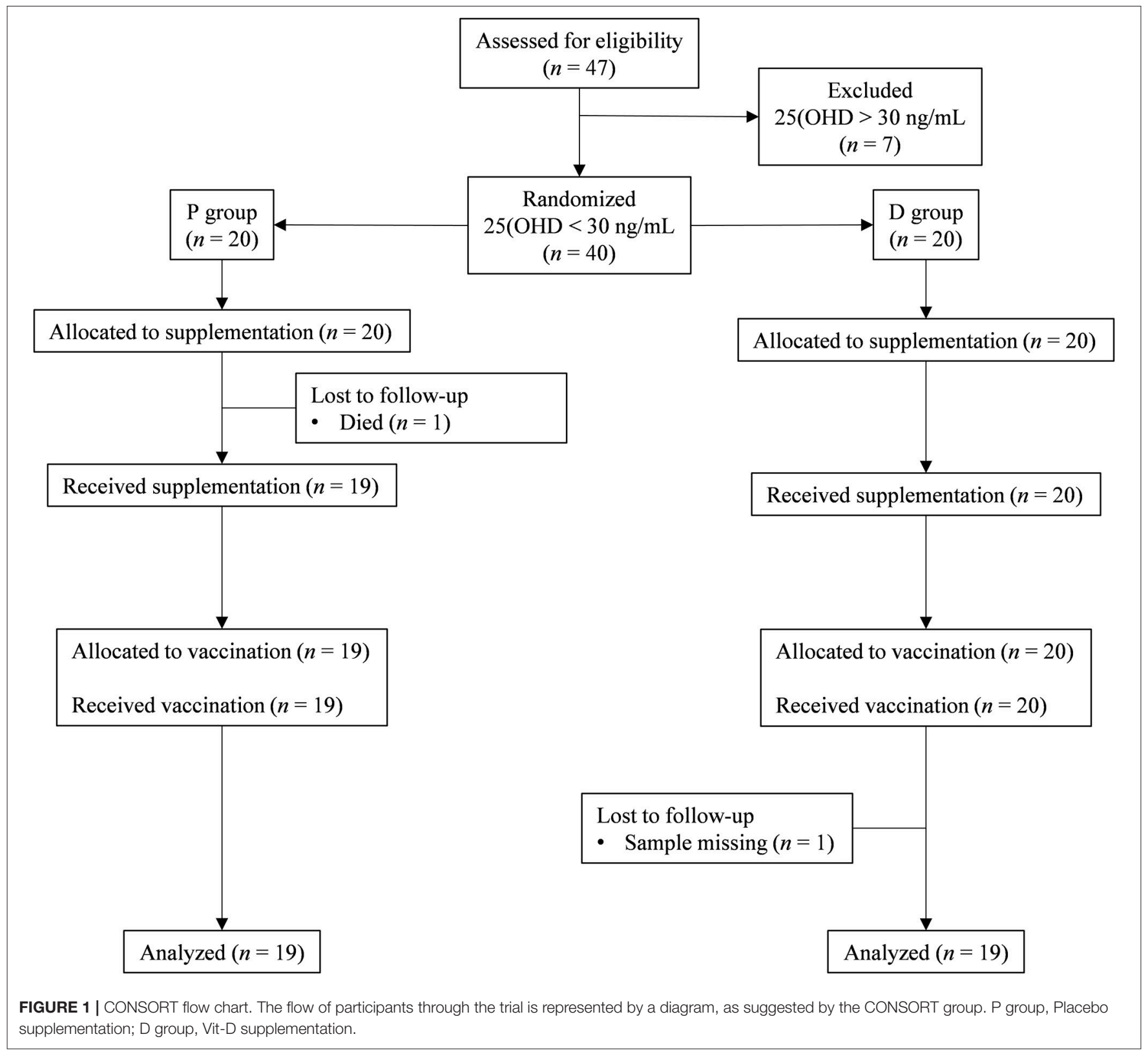

\section{RESULTS}

\section{Volunteer Inclusion and Follow-Up}

The volunteers were recruited over 2 years (2013 and 2014) on a similar schedule: the first visit (V1) in June, the second in October at the end of supplementation and for vaccination (V2), and the third in November, 28 days after vaccination (V3). Because of recruitment difficulties, the number of volunteers selected $(n=47)$ was half the original intended sample size $(n$ $=84$ ). An intermediary analysis was conducted, and showed a discrepancy between the initial hypothesis and the results obtained for cathelicidin. For these reasons, and because the vaccine strains were set to change the following year (2015), we decided to end recruitment.
Of the 47 eligible volunteers, 38 Vit-D-deficient individuals were analyzed in the placebo $(n=19)$ and Vit-D $(n=$ 19) groups; the causes of drop-out are indicated in the flow chart (Figure 1). Volunteer characteristics at inclusion showed no difference between the two groups (Table 1). All plasma biochemical markers were within the normal ranges.

A telephone follow-up after 6 weeks confirmed subjects' clinical safety, and the absence of side effects from the supplementation. Volunteer compliance for the Vit-D or placebo supplementation, assessed by serum vitamin D quantification, was satisfactory. A biological test after 2 months of supplementation showed neither serum Vit-D $>75 \mathrm{ng} / \mathrm{mL}$ nor hypercalcemia nor hypercalciuria. 
TABLE 1 | Characteristics of healthy volunteers at inclusion ${ }^{1}$.

\begin{tabular}{|c|c|c|c|}
\hline & P group $(n=19)$ & D group $(n=19)$ & $p^{2}$ \\
\hline \multicolumn{4}{|c|}{ ANTHROPOMETRIC PARAMETERS } \\
\hline Sex ratio, $m / f$ & $12 / 8$ & $11 / 9$ & 0.99 \\
\hline Age, $y$ & $70 \pm 6$ & $72 \pm 5$ & 0.99 \\
\hline Height, cm & $166 \pm 7$ & $165 \pm 8$ & 0.99 \\
\hline Weight, kg & $75 \pm 12$ & $72 \pm 14$ & 0.99 \\
\hline Body mass index, $\mathrm{kg} / \mathrm{m}^{2}$ & $27.3 \pm 3.9$ & $26.3 \pm 3.5$ & 0.99 \\
\hline Abdominal perimeter, cm & $99 \pm 10$ & $96 \pm 12$ & 0.99 \\
\hline \multicolumn{4}{|c|}{ BIOLOGICAL PARAMETERS } \\
\hline Sodium, mmol. $\mathrm{L}^{-1}$ & $140 \pm 2$ & $140 \pm 2$ & 0.99 \\
\hline Potassium, mmol. $L^{-1}$ & $4 \pm 0.4$ & $4 \pm 0.2$ & 0.99 \\
\hline Chloride, $\mathrm{mmol} . \mathrm{L}^{-1}$ & $106 \pm 2$ & $104 \pm 2$ & 0.99 \\
\hline Total proteins, $g . L^{-1}$ & $76 \pm 3$ & $75 \pm 4$ & 0.99 \\
\hline Glucose, $m m o l . L^{-1}$ & $5.2 \pm 0.9$ & $5.0 \pm 0.9$ & 0.99 \\
\hline Calcium, mmol. $L^{-1}$ & $2.2 \pm 0.1$ & $2.2 \pm 0.1$ & 0.99 \\
\hline Urea, $m m o l . L^{-1}$ & $6.3 \pm 1.5$ & $6.0 \pm 1.1$ & 0.99 \\
\hline Creatinine, $\mu \mathrm{mol} . \mathrm{L}^{-1}$ & $72 \pm 13$ & $76 \pm 14$ & 0.99 \\
\hline Phosphorus, mmol. $\mathrm{L}^{-1}$ & $0.9 \pm 0.1$ & $0.9 \pm 0.1$ & 0.99 \\
\hline AST, UI.L-1 & $22 \pm 7$ & $22 \pm 7$ & 0.99 \\
\hline$A L T, U I . L^{-1}$ & $27 \pm 9$ & $27 \pm 9$ & 0.99 \\
\hline $25-\mathrm{OH}$ vitamin $\mathrm{D}, \mathrm{ng} \cdot \mathrm{mL}^{-1}$ & $19.7 \pm 5.9$ & $20.7 \pm 5.7$ & 0.99 \\
\hline
\end{tabular}

P group, Placebo supplemented group; D group, Vit-D supplemented group.

${ }^{1}$ Data are expressed as mean $\pm S D$.

2 p-values were determined using a Mann-Whitney U-test.

\section{Serum Vitamin D}

At inclusion, no statistical difference in serum Vit-D level was observed between the groups (P: $19.7 \pm 5.9 \mathrm{ng} / \mathrm{mL}, \mathrm{D}: 20.7 \pm$ $5.7 \mathrm{ng} / \mathrm{mL}$, Figure 2). For the $\mathrm{P}$ group, no variation was found during the entire protocol (V1: $19.4 \pm 6.24 \mathrm{ng} / \mathrm{mL}, \mathrm{V} 2: 19.1 \pm$ $7.9 \mathrm{ng} / \mathrm{mL}, \mathrm{V} 3: 18.1 \pm 6.7 \mathrm{ng} / \mathrm{mL}$ ). For the $\mathrm{D}$ group, a significant increase was observed after the supplementation period (V1:20.7 \pm 5.7 to V2: $44.3 \pm 8.6 \mathrm{ng} / \mathrm{mL}, p<0.001$ ), and for all subjects, 25 $(\mathrm{OH}) \mathrm{D}$ concentration was $>30 \mathrm{ng} / \mathrm{mL}$ at V2. The highest serum $25-(\mathrm{OH}) \mathrm{D}$ level was $58 \mathrm{ng} / \mathrm{mL}$ with the 600,000 IU cumulative Vit-D dose. This supplementation was demonstrated to be safe: no variation in plasma or urinary calcium levels and no clinically relevant adverse effects were observed. One month after the end of the supplementation (V3), no significant decrease in serum Vit-D level was observed in the D group (V3: $36.5 \pm 6.3$ vs. V2: $44.3 \pm 8.6 \mathrm{ng} / \mathrm{mL})$.

\section{Serum Cathelicidin}

At inclusion (V1), no statistical difference between groups was observed in serum cathelicidin levels (P: $62.0 \pm 5.5 \mathrm{ng} / \mathrm{mL}, \mathrm{D}$ : $66.2 \pm 6.9 \mathrm{ng} / \mathrm{mL}$, Figure 3). The highest and lowest values were similar (P: $24-121 \mathrm{ng} / \mathrm{mL}, \mathrm{D}: 25-120 \mathrm{ng} / \mathrm{mL}$ ), although there was a greater dispersion of values in the $\mathrm{P}$ group than in the $\mathrm{D}$ group. No variation was observed in any period (V2, V3) in either group.

No correlation was found between serum Vit-D and cathelicidin levels for volunteers at inclusion $(r=-0.24, p=$ 0.14 , Figure 4A). Moreover, considering the data before and after supplementation for the D group, no significant relationship
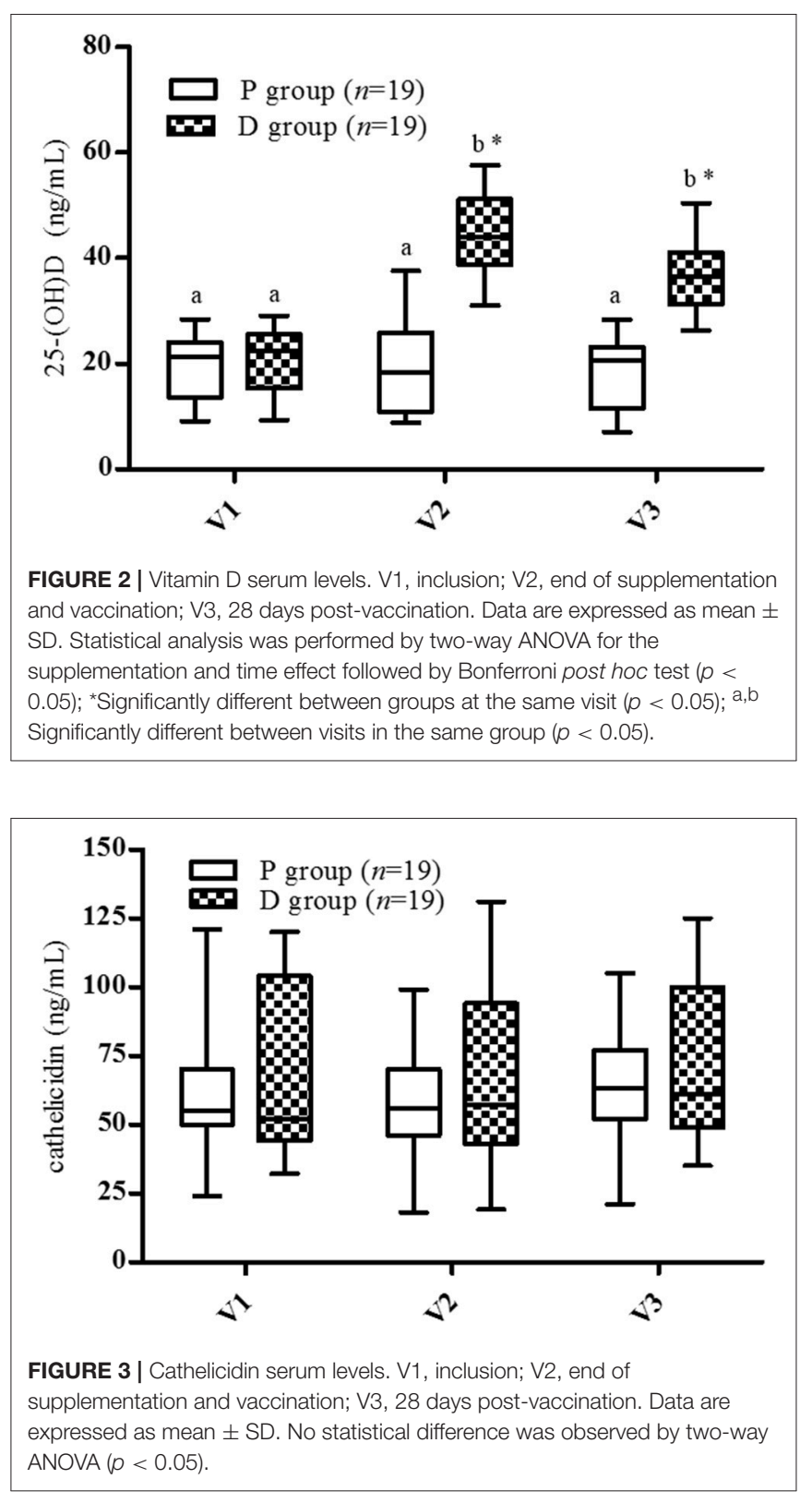

between cathelicidin and 25-(OH)D serum levels was observed $(r=-0.10, p=0.53$, Figure 4B).

\section{Antibody Response to Influenza Vaccination}

Ab titers to inactivated influenza virus strains are presented in Table 2. The Ab titers increased significantly for the three strains after vaccination in both $\mathrm{P}$ and $\mathrm{D}$ groups except for $\mathrm{H} 1 \mathrm{~N} 1$ in $\mathrm{D}$ group, because of data dispersion (Table 2; $p^{2}, p^{3}$ ). For the pre-vaccination $\mathrm{Ab}$ titers, there was no significant difference between the groups for any strain (Table $2 ; p^{4}$ ). Nor was there any significant difference for post-vaccination Ab titers, except for the H3N2 strain which was significantly lower in the D than the P group (Table $2 ; p^{5}$ ). No significant differences were observed after vaccination between $\mathrm{P}$ and $\mathrm{D}$ groups in either 

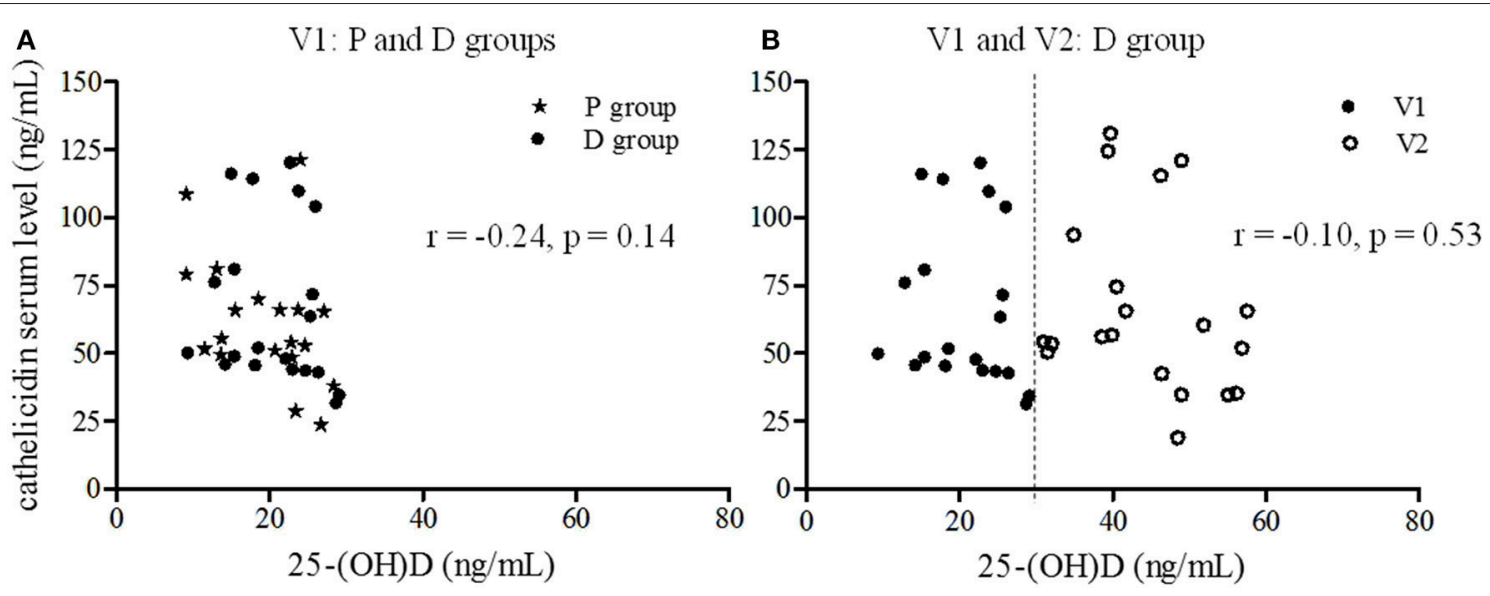

FIGURE 4 | Correlation between 25-(OH)D and cathelicidin serum levels. The relationship between cathelicidin and 25-(OH)D serum levels was estimated using Pearson correlation. (A) Correlation at inclusion (V1) for all volunteers (star P group, circle D group) $(r=-0.24, p=0.14)$. (B) Correlation before (V1: dark circle) and after the supplementation period (V2: light circle) for D group $(r=-0.10, p=0.53)$.

TABLE 2 | Antibody response to inactivated influenza virus vaccine in all volunteers ${ }^{1}$.

Ab titers $-P$ group $(n=19)$

Ab titers $-D$ group $(n=19)$

\begin{tabular}{|c|c|c|c|c|c|c|c|c|c|c|c|}
\hline Vaccine strain & Pre-vaccination & Post-vaccination & $p^{2}$ & Ratio post/pre & Pre-vaccination & Post-vaccination & $p^{3}$ & Ratio post/pre & $p^{4}$ & $p^{5}$ & $p^{6}$ \\
\hline I3N2 & $29.4(12.9-45.9)$ & $107(86.5-127)$ & 0.0005 & $3.5 \pm 2.6$ & $17.9(6.0-29.8)$ & $51.6(36.5-66.7)$ & 0.001 & $3.0 \pm 1.2$ & 0.225 & 0.046 & 0.397 \\
\hline
\end{tabular}

P group, Placebo supplemented group; D group, Vit-D supplemented group.

${ }^{1}$ Ab titers are expressed as GMT $(95 \% \mathrm{Cl})$.

${ }^{2,3}$ Determined using a paired Wilcoxon test for intra-group differences between pre- and post-vaccination $A b$ titers in the $P$ group $\left(p^{2}\right)$ and in the $D$ group $\left(p^{3}\right)$.

${ }^{4,5,6}$ Determined using Mann-Whitney U-test for inter-group differences in pre-vaccination Ab titers $\left(p^{4}\right)$, in post-vaccination $A b$ titers $\left(p^{5}\right)$ and $A b$ titers ratio $\left(p^{6}\right)$ between $P$ and $D$ groups.

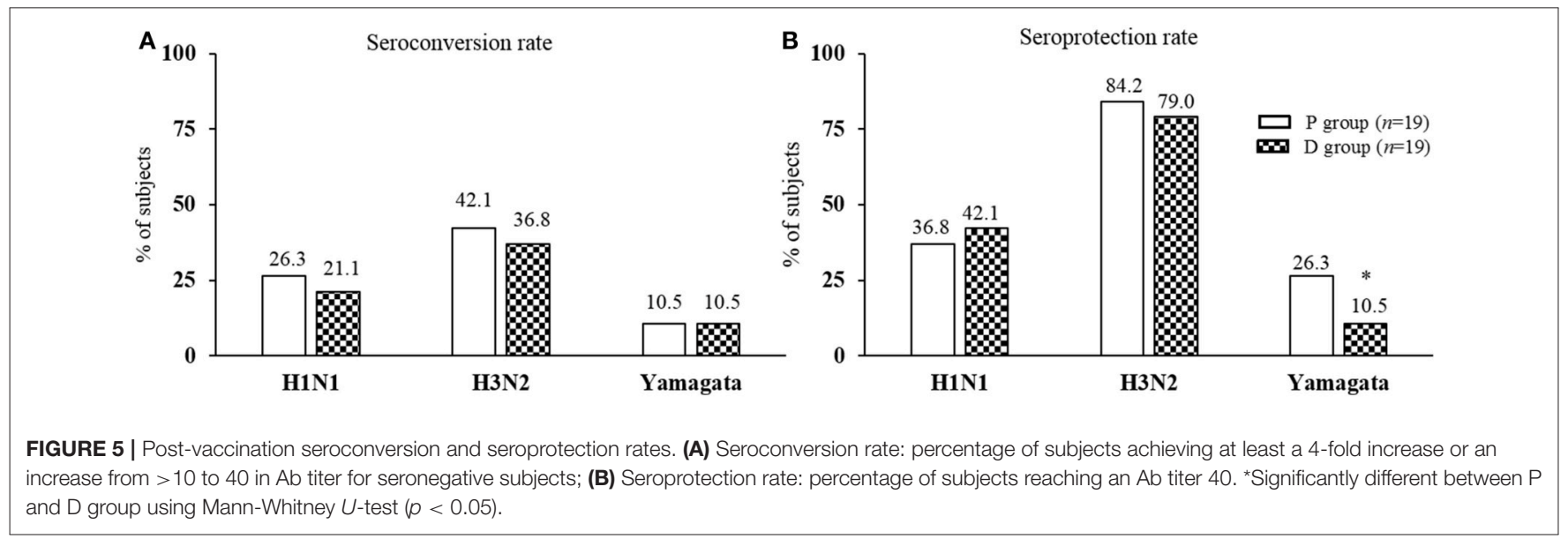

seroconversion (Figure 5A) or seroprotection (Figure 5B) rates, except for Yamagata seroprotection (P: $26.3 \%$ vs. D: $10.5 \%$, $p<$ $0.05)$. This data needed to be stratified with regards to volunteers' serologic status before vaccination.

For the seronegative volunteers, the Ab titer for each strain increased significantly $(p<0.05)$ after vaccination in both $\mathrm{P}$ and $\mathrm{D}$ groups, with a significantly lower level of H3N2 in the $\mathrm{D}$ than in the $\mathrm{P}$ group $(p<0.05$; Figures $6 \mathrm{~A}-\mathrm{C})$. For seropositive volunteers, the $\mathrm{Ab}$ titer of the three strains increased significantly $(p<0.05)$ after vaccination in the $\mathrm{P}$ group, although in the D group only the $\mathrm{H} 3 \mathrm{~N} 2$ strain increased significantly (Figures 6A-C). Looking at the post-vaccination data as a whole, the seronegative volunteers had fewer Ab titers than the seropositive volunteers. 


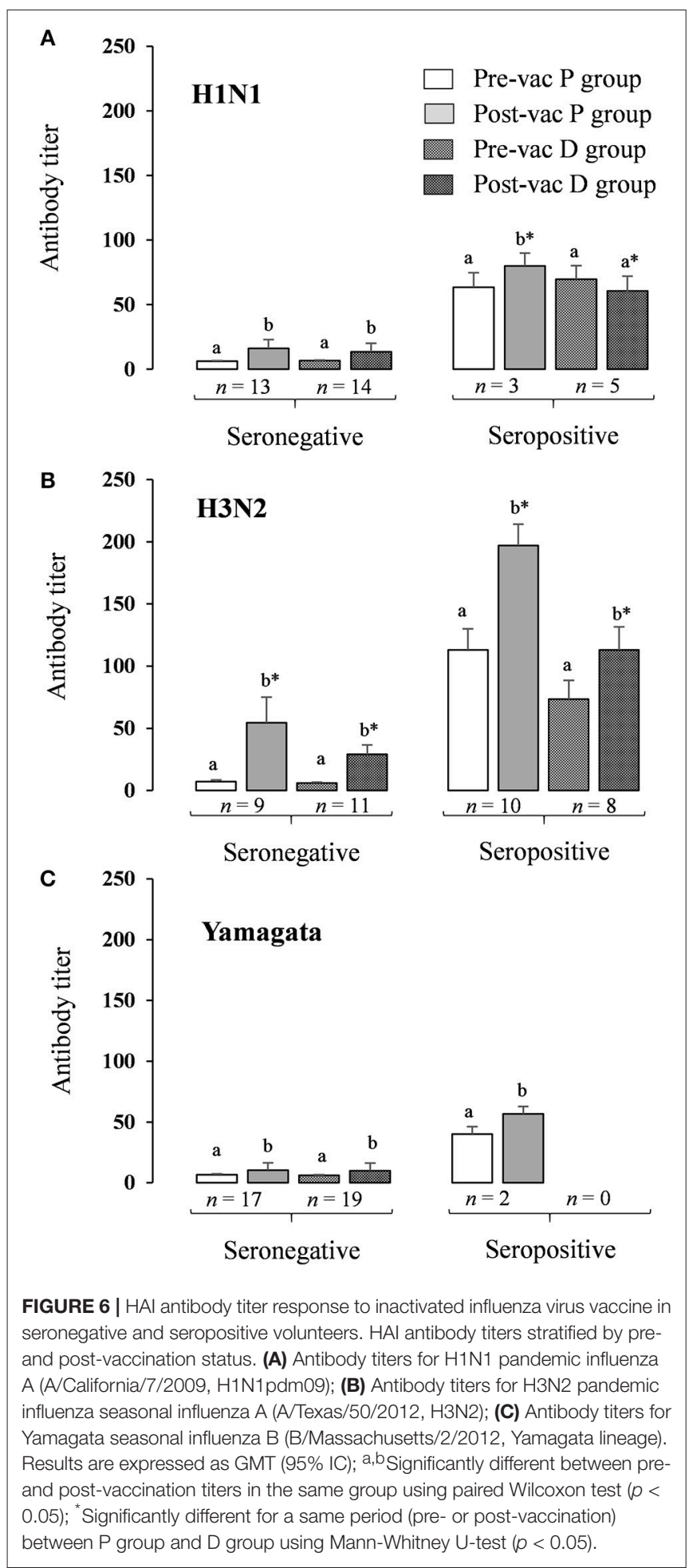

\section{Cytokine Profile}

The plasma cytokine levels were determined to evaluate the T-cell response at each period (V1, V2, and V3): Th1 (IFN $\gamma$, TNF $\alpha$ ), Th2 (IL-5, IL-6, IL-10, IL-13), Th17 (IL-17A, IL-23), and Treg (TGF $\beta$ ) (Table 3). No data is available for IL-10 and IL-13 because sample concentrations were below the limit of quantification.

The IFN $\gamma$ and IL-5 plasma levels were similar irrespective of group or period, with no variation in the IFN $\gamma / \mathrm{IL}-5$ ratio (P$\mathrm{V} 1: 7.16 \pm 2.11, \mathrm{~V} 2: 4.81 \pm 1.60 ; \mathrm{D}-\mathrm{V} 1: 7.48 \pm 2.33$, V2: 5.50 $\pm 2.11)$. Significantly lower levels of TNF $\alpha$ (V2, $p=0.0478, U-$ test) and IL-6 ( $p=0.046$, ANOVA) were observed in the D than in the $\mathrm{P}$ group, with no significant variation in TNF $\alpha / \mathrm{IL}-6$ ratio $(\mathrm{P}-\mathrm{V} 1: 3.06 \pm 0.45, \mathrm{~V} 2: 4.21 \pm 1.14 ; \mathrm{D}-\mathrm{V} 1: 3.22 \pm 0.53, \mathrm{~V} 2$ : $2.74 \pm 0.45)$.

No change was observed in the Th17-cytokine response (IL17A and IL-23) either between groups or over different periods. The level of TFG $\beta$ was significantly higher in the $\mathrm{D}$ than in the $\mathrm{P}$ group after vaccination (V3, $p=0.0028, U$-test) and in V2 than $\mathrm{V} 3$ in the $\mathrm{D}$ group $(p=0.0084$, Wilcoxon test).

\section{Indoleamine-2,3-deoxygenase (IDO) Activity}

We evaluated serum IDO activity through the Kyn to Trp concentrations ratio. No significant differences were observed in IDO activity in any group or period (Table 4).

\section{T Cell Phenotypes and PMN ROS Production}

Lymphocyte polarization phenotyping was based on coexpression of CD3, CD4, and specific surface markers of Th1 (CXCR3), Th2 (CrTh2), Th17 (CCR6), and Treg (CD125+, $\mathrm{CD}_{127^{-}}$) (Figure 7B). Percentages of Th cells did not vary over periods or between groups, except for a significant decrease in the Th1 to Th2 ratio observed when comparing the $\mathrm{D}$ group to the $\mathrm{P}$ group at the end of Vit-D supplementation (V2).

The PMN basal ROS production, expressed in fluorescence arbitrary unit, did not vary over periods or between groups $(\mathrm{P}$ - V1:29.0 \pm 2.8; V2: 29.1 \pm 2.9; V3: $36.8 \pm 3.8$; D - V1: $28.5 \pm 2.4$; V2: $35.6 \pm 3.6 ; \mathrm{V} 3: 41.3 \pm 4.6)$.

\section{DISCUSSION}

By analyzing several immune biomarkers, this trial assessed the effects of Vit-D supplementation on the response to influenza vaccination in Vit-D-deficient elderly persons.

The study carries limitations that warrant consideration. Firstly, the differences in volunteers' vaccine status before vaccination may have limited the ability to observe the effects of Vit-D supplementation on influenza vaccination response. Secondly, the small sample size, which could mean the study was underpowered to detect changes in serum cathelicidin levels despite volunteers' well-defined Vit-D deficiency status and the significant (2-fold) increase in Vit-D level in the supplemented group. The lack of a reference analytical method and physiological ranges for serum cathelicidin may further compound this issue. Consequently, the study power calculated on cathelicidin variations with Vit-D supplementation was reduced from 80 to $47 \%$.

At the end of Vit-D supplementation $(100,000$ UI $\times 6)$, the mean change in serum Vit-D level ranged from +16.7 to 
TABLE 3 | Cytokine plasma levels ${ }^{1}$.

\begin{tabular}{|c|c|c|c|c|c|c|c|c|c|}
\hline & \multicolumn{3}{|c|}{ P group $(n=19)$} & \multicolumn{3}{|c|}{ D group $(n=19)$} & \multicolumn{3}{|c|}{$p^{2}$} \\
\hline & V1 & V2 & V3 & V1 & V2 & V3 & Vit-D & Visit & Interaction \\
\hline $\mathrm{IFN} \gamma(\mathrm{pg} / \mathrm{mL})$ & $3.76 \pm 0.99$ & $2.48 \pm 0.74$ & $3.16 \pm 1.09$ & $3.59 \pm 1.13$ & $2.99 \pm 1.06$ & $3.35 \pm 1.15$ & 0.067 & 0.384 & 0.685 \\
\hline $\mathrm{TNF} \alpha(\mathrm{pg} / \mathrm{mL})$ & $3.89 \pm 0.58$ & $3.87 \pm 0.95^{3}$ & $3.87 \pm 0.88$ & $3.05 \pm 0.44$ & $2.49 \pm 0.44^{3}$ & $2.81 \pm 0.57$ & 0.040 & 0.905 & 0.919 \\
\hline II-5 (pg/mL) & $1.00 \pm 0.53$ & $0.87 \pm 0.37$ & $0.72 \pm 0.18$ & $0.88 \pm 0.29$ & $0.66 \pm 0.14$ & $0.91 \pm 0.22$ & 0.868 & 0.847 & 0.800 \\
\hline II-6 (pg/mL) & $1.49 \pm 0.32$ & $1.11 \pm 0.18$ & $1.13 \pm 0.20$ & $1.09 \pm 0.16$ & $0.90 \pm 0.01$ & $0.86 \pm 0.03$ & 0.046 & 0.179 & 0.866 \\
\hline IL-17A (pg/mL) & $0.71 \pm 0.23$ & $0.57 \pm 0.04$ & $0.90 \pm 0.29$ & $1.07 \pm 0.33$ & $0.81 \pm 0.15$ & $1.03 \pm 0.19$ & 0.511 & 0.384 & 0.474 \\
\hline IL-23 (pg/mL) & $303 \pm 101$ & $250 \pm 114$ & $295 \pm 194$ & $337 \pm 103$ & $322 \pm 99.8$ & $236 \pm 95.0$ & 0.870 & 0.902 & 0.856 \\
\hline TGF $\beta$ (ng/mL) & $9.88 \pm 2.23$ & $14.2 \pm 3.87$ & $11.5 \pm 3.70^{4}$ & $13.6 \pm 2.55$ & $11.4 \pm 2.27$ & $20.8 \pm 3.37^{4,5}$ & 0.175 & 0.321 & 0.145 \\
\hline
\end{tabular}

P group, Placebo supplemented group; D group, Vit-D supplemented group; V1, inclusion; V2, end of supplementation and vaccination; V3, 28 days post-vaccination.

${ }^{1}$ Results are expressed as mean \pm SEM.

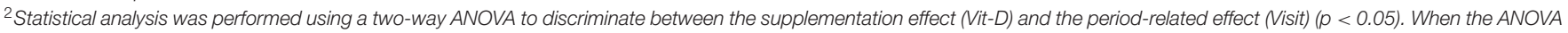
indicated significant interactions, the Bonferroni post hoc test was used.

${ }^{3}$ Significant difference between $P$ and $D$ groups at V2 using Mann-Whitney $U$-test $(p<0.05)$.

${ }^{4}$ Significant difference between $P$ and $D$ groups at V3 using Mann-Whitney U-test $(p<0.05)$.

${ }^{5}$ Significant difference for $D$ group between V2 and V3 using paired Wilcoxon test $(p<0.05)$.

TABLE 4 | Indoleamine-2,3-deoxygenase serum activity ${ }^{1}$.

\begin{tabular}{|c|c|c|c|c|c|c|c|c|c|}
\hline & \multicolumn{3}{|c|}{$P$ group $(n=10)$} & \multicolumn{3}{|c|}{$D$ group $(n=9)$} & \multicolumn{3}{|c|}{$p^{2}$} \\
\hline & V1 & V2 & V3 & V1 & V2 & V3 & Vit-D & Visit & Interaction \\
\hline Kyn ( $\mu \mathrm{mol} / \mathrm{L})$ & $2.4 \pm 0.2$ & $2.1 \pm 0.6$ & $2.6 \pm 0.4$ & $2.4 \pm 0.1$ & $2.0 \pm 0.2$ & $2.2 \pm 0.2$ & 0.192 & 0.363 & 0.882 \\
\hline $\operatorname{Trp}(\mu \mathrm{mol} / \mathrm{L})$ & $47.0 \pm 2.5$ & $42.1 \pm 2.3$ & $46.9 \pm 3.5$ & $46.9 \pm 2.8$ & $43.8 \pm 2.8$ & $44.5 \pm 3.8$ & 0.309 & 0.918 & 0.811 \\
\hline Kyn/Trp ratio (x100) & $5.2 \pm 0.5$ & $5.0 \pm 0.3$ & $5.3 \pm 0.3$ & $5.1 \pm 0.6$ & $4.5 \pm 0.5$ & $5.2 \pm 0.8$ & 0.533 & 0.564 & 0.888 \\
\hline
\end{tabular}

P group, Placebo supplemented group; D group, Vit-D supplemented group; V1, inclusion; V2, end of supplementation and vaccination; V3: 28 days post-vaccination.

${ }^{1}$ IDO activity was estimated by Kyn/Trp ratio. Data are expressed as mean \pm SEM.

${ }^{2}$ Statistical analysis was performed using a two-way ANOVA to discriminate between the supplementation effect (Vit-D) and the period-related effect (Nisit) ( $\left.p<0.05\right)$.

$+37.1 \mathrm{ng} / \mathrm{mL}$, corresponding to $0.23-0.52 \mathrm{ng} / \mathrm{mL}$ for $100 \mathrm{IU}$. This is in line with data from Schleck et al. (38), who reported an increase of $0.30-0.46 \mathrm{ng} / \mathrm{mL}$ for $100 \mathrm{IU}$ after a 12 -week treatment. The serum Vit-D level quickly decreased after supplementation ended (by approximately $18 \%$ in 4 weeks), suggesting a shortlived efficacy. In our conditions, the Vit-D supplementation induced no adverse events, and others have demonstrated that doses larger than those used here are safe (39).

The antimicrobial properties of Vit-D have been extensively studied with respect to tuberculosis, where Vit-D enhances cathelicidin production and autophagy (40). These effects have also been described in viral infections such as HIV and respiratory diseases (40). At inclusion in our trial, volunteers showed a wide range of cathelicidinemia (from 29 to $121 \mathrm{ng} / \mathrm{mL}$ ).In healthy elderly Chinese persons, Yang et al. reported, using the same ELISA method, lower levels of cathelicidin $(20.7 \pm 5.8 \mathrm{ng} / \mathrm{mL})$ associated with Vit-D concentrations $(18.1 \pm 9.4 \mathrm{ng} / \mathrm{mL})$ similar to those observed in our study (41). Using another ELISA method in a healthy population, Bhan et al. (42), and Dixon et al. (43) established a positive correlation between serum cathelicidin and Vit-D levels when 25-(OH)D concentration was lower than $32 \mathrm{ng} / \mathrm{mL}$. However, we did not find this correlation, despite subjects' 25$(\mathrm{OH}) \mathrm{D}$ concentrations being under $32 \mathrm{ng} / \mathrm{ml}$. Similarly, several authors reported no change in circulating cathelicidin $(44,45)$, although Vit-D supplementation resulted in leukocyte increased cathelicidin mRNA expression (46). There could be a Vit-Dindependent regulation of cathelicidin expression, or of cleaving activity of serine proteinase 3 , or of cathelicidin proteolysis (12). Also, owing to its polycationic structure, blood free cathelicidin is rapidly bound to negatively-charged compounds, and so is unavailable for quantification. These various factors may explain why it is so difficult to demonstrate a Vit-D-induced increase in serum cathelicidin concentration.

The effect of 25- $(\mathrm{OH}) \mathrm{D}$ supplementation on the humoral immune response to influenza vaccination was evaluated. It showed no effect on $\mathrm{Ab}$ production in either seroprotection or seroconversion. This finding is consistent with two randomized controlled trials of Vit-D supplementation in influenzavaccinated healthy adults (34) and adolescents (47). These trials did not characterize the Vit-D status prior to the supplementation, unlike our study.

The volunteers' seroprotection (11-84\%) and seroconversion rates (10-42\%) were in line with data from the CDC, suggesting a clinical efficacy of $17-53 \%$ in elderly persons (30). The pre-vaccination $\mathrm{Ab}$ status must be taken into account when considering the effect of Vit-D supplementation on vaccine response. Since almost all of the volunteers had been vaccinated 


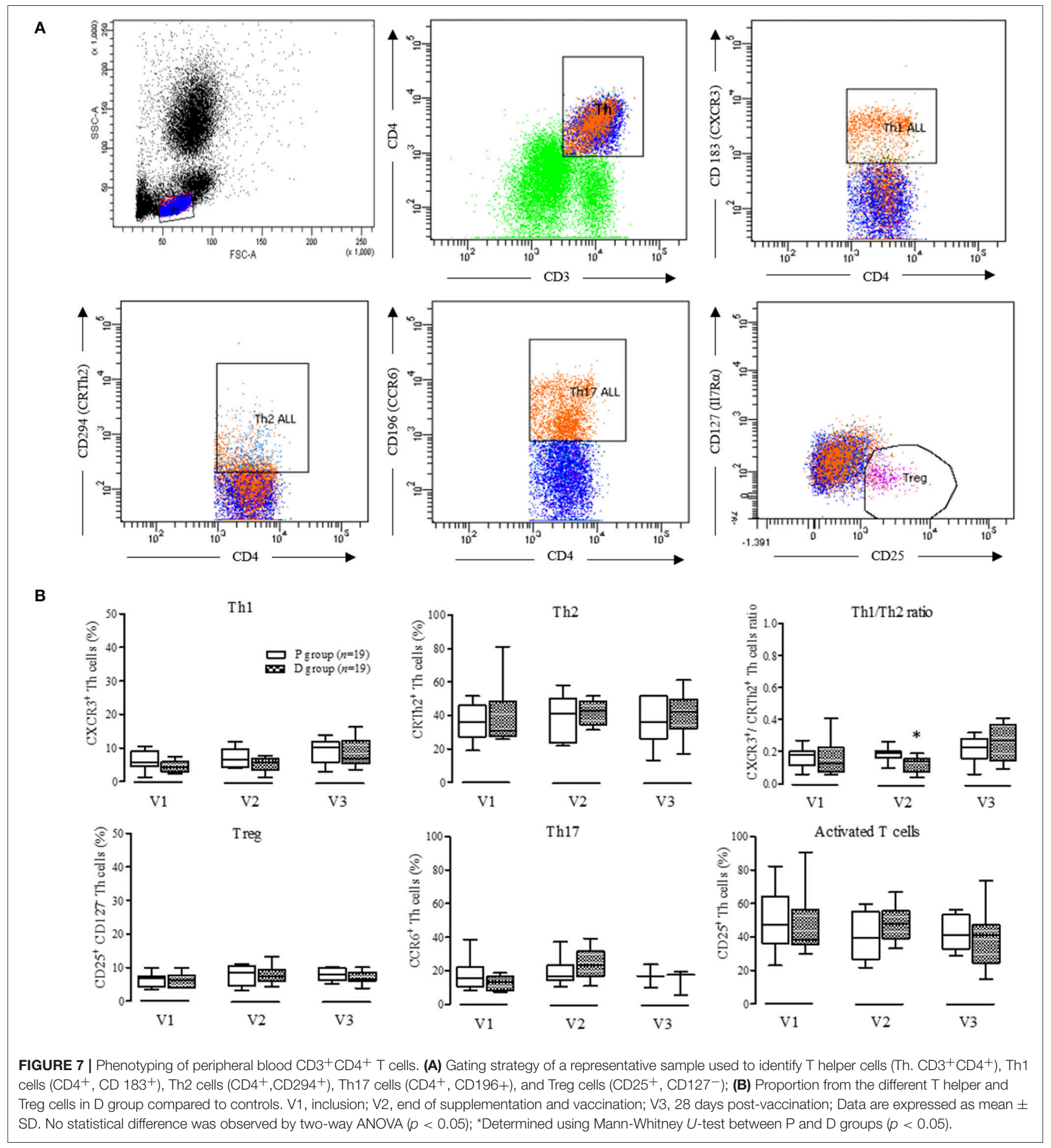

in the previous year, high levels of pre-vaccination $\mathrm{Ab}$ titer were expected. The pre-vaccination Ab titers for type A strains in both $\mathrm{P}$ and $\mathrm{D}$ groups were lower than those in previous reports (48). Hirota et al. (48) showed a significant inverse association of pre-vaccination serologic status with both titer fold rise and response rate in the serum $\mathrm{Ab}$. In our study, a subgroup analysis of pre-vaccination $\mathrm{Ab}$ titers showed that the seroconversion rate was not affected by Vit-D-supplementation, but was lower for seronegative subjects than for seropositive ones. McElhaney reported that elderly persons who had been vaccinated every year were better protected than those who were vaccinated for the first time, suggesting that the absolute post-vaccination $\mathrm{Ab}$ titer is a 
better marker of protection than the Ab mean fold increase (49). In our study, the "intact" $\mathrm{Ab}$ response to the vaccine, defined by Hara et al. (50) as one showing post-vaccination HAI titer $\geq 40$ for at least one strain, was similar in both groups (84\%).

Considering the innate immune response, Vit-D supplementation induced a shift to a Th2-cytokine response as previously described (increased levels of IL-4, IL-5, IL-10, and reduced levels of IL-2, IFN $\gamma$, and TNF $\alpha)(21,22)$. In our study, we confirmed that Vit-D supplementation significantly reduced the plasma level of TNF $\alpha$ and IL-6. Limited data from observational studies lends support to an anti-inflammatory role of vitamin $\mathrm{D}$. In an observational study conducted with 957 adults (>60 y), Laird et al. (51) showed a significant association between low vitamin $\mathrm{D}$ status $(25-(\mathrm{OH}) \mathrm{D}<25$ $\mathrm{nmol} / \mathrm{L}$ ) and inflammation markers including IL-6, TNF $\alpha$, IL-10, and CRP.

After Vit-D supplementation we noted a significant decrease in the Th1/Th2 ratio in link with TNF $\alpha$ and IL- 6 reduced levels. This is in accordance with Penna's data (52) showing that 1,25$(\mathrm{OH})_{2} \mathrm{D}$ can inhibit Th1 differentiation (via expression of IFN $\gamma$ ) and increase the Th2 response by stimulating IL-5 production. The IFN- $\gamma / \mathrm{IL}-5$ ratio is of interest when evaluating the Th1/Th2 balance $(53,54)$.

Interestingly, the Vit-D supplementation was associated with an increase in TGF $\beta$ plasma levels after influenza vaccination, while no change in the Treg cell sub-population was observed. Likewise, previous studies showed that neuraminidase from influenza vaccine strains directly activates TGF $\beta$ production (55), which contributes to the tolerogenic effect of Vit-D on cell-mediated immunity (44). Increased IDO activity has been associated with tolerogenic immune responses $(56,57)$. In our study, IDO activity was not changed after Vit-D supplementation, which is consistent with an unchanged Treg sub-population.

Previous results (58) demonstrate that $1,25-(\mathrm{OH})_{2} \mathrm{D}$ strongly up-regulates the cathelicidin gene and protein expression NOX2dependently, and induces antibacterial activity by $\mathrm{NADPH}$ oxidase pathway in phagocytes (19). In our conditions, we did not observe any effect on PMN ROS production after Vit$\mathrm{D}$ supplementation. These conflicting findings highlight the need to characterize the role of the NOX2-dependent ROS signaling pathway in Vit-D-induced cathelicidin's anti-infectious effects.

\section{REFERENCES}

1. Dushoff J. Mortality due to Influenza in the United States-an annualized regression approach using multiple-cause mortality data. Am J Epidemiol. (2005) 163:181-7. doi: 10.1093/aje/kwj024

2. Liu WM, Nahar TER, Jacobi RHJ, Gijzen K, van Beek J, Hak E, et al. Impaired production of TNF- $\alpha$ by dendritic cells of older adults leads to a lower CD8+ T cell response against influenza. Vaccine (2012) 30:1659-66. doi: 10.1016/j.vaccine.2011.12.105

3. Vasson M-P, Farges M-C, Goncalves-Mendes N, Talvas J, Ribalta J, Winklhofer-Roob B, et al. Does aging affect the immune status? A comparative analysis in 300 healthy volunteers from France, Austria and Spain. Immun Ageing A (2013) 10:10-38. doi: 10.1186/1742-4933-10-38

\section{CONCLUSION}

Our data demonstrate for the first time that Vit-D supplementation in deficient elderly persons promotes a higher TGF $\beta$ plasma level in response to influenza vaccination without improving antibody production. The Vit-D supplementation seems to direct the lymphocyte polarization toward a tolerogenic immune response as suggested by the lower Th1/Th2 ratio compared to controls. Taken together, our results suggest that vitamin $\mathrm{D}$ supplementation in deficient elderly persons is not an effective way to improve their antibody response to influenza vaccine. A deeper characterization of metabolic and molecular pathways of these observations will aid in the understanding of vitamin D's effects on cell-mediated immunity in deficient elderly persons.

\section{AUTHOR CONTRIBUTIONS}

NG-M, AG, BE, HL, and M-PV designed the protocol. NG-M, JT, $\mathrm{PB}$, and MP-V performed the experiments, analyzed the data and wrote the manuscript. CD and VC conducted the medical visits. GM and VS participated to the biological analysis and serum vit D quantification. All authors read and approved the manuscript.

\section{FUNDING}

This work was supported by clinical research program funding from the CHU Clermont-Ferrand, by research program funding from the French Ministry of Education, Research and Innovation, and by the 2015 Bernard Beaufrère research prize from the French Society of Clinical Nutrition and Metabolism (SFNEP).

\section{ACKNOWLEDGMENTS}

We authors thank all the volunteers who agreed to participate in the trial. They are grateful to the Clinical Investigation Center (Prof C. Dubray, Dr. G. Pickering, S. Boulliau, F. Girond, N. Macian, S. Eschalier), the hospital pharmacy for product delivery, C. Blavignac (Cell Imagery Center), and L. Monbrun (Genotoul Anexplo, Toulouse) for cytokine analysis, and Prof B. Lina (Hôpital de la Croix-Rousse, Lyon) for HAI titer assays. They also thank L. Slimani and S. Rougé for their technical assistance.

4. Pera A, Campos C, López N, Hassouneh F, Alonso C, Tarazona R, et al. Immunosenescence: Implications for response to infection and vaccination in older people. Maturitas (2015) 82:50-5. doi: 10.1016/j.maturitas.2015. 05.004

5. Simon AK, Hollander GA, McMichael A. Evolution of the immune system in humans from infancy to old age. Proc R Soc B Biol Sci. (2015) 282:20143085. doi: $10.1098 / \mathrm{rspb} .2014 .3085$

6. Holick MF. Vitamin D deficiency. N Engl J Med. (2007) 357:266-81. doi: 10.1056/NEJMra070553

7. Rosen CJ, Abrams SA, Aloia JF, Brannon PM, Clinton SK, DurazoArvizu RA, et al. IOM committee members respond to Endocrine Society vitamin D guideline. J Clin Endocrinol Metab (2012) 97:1146-52. doi: 10.1210/jc.2011-2218 
8. Castetbon K, Vernay M, Malon A, Salanave B, Deschamps V, Roudier C, et al. Dietary intake, physical activity and nutritional status in adults: the French nutrition and health survey (ENNS, 2006-2007). Br J Nutr. (2009) 102:733-43. doi: 10.1017/S0007114509274745

9. Takahashi K, Nakayama Y, Horiuchi H, Ohta T, Komoriya K, Ohmori $\mathrm{H}$, et al. Human neutrophils express messenger RNA of vitamin D receptor and respond to lalpha,25-dihydroxyvitamin D3. Immunopharmacol Immunotoxicol. (2002) 24:335-47. doi: 10.1081/IPH-120014721

10. Hewison M, Freeman L, Hughes SV, Evans KN, Bland R, Eliopoulos AG, et al. Differential regulation of vitamin D receptor and its ligand in human monocyte-derived dendritic cells. J Immunol. (2003) 170:5382-90. doi: 10.4049/jimmunol.170.11.5382

11. Chen S, Sims GP, Chen XX, Gu YY, Chen S, Lipsky PE. Modulatory effects of 1,25-dihydroxyvitamin D3 on human B cell differentiation. J Immunol. (2007) 179:1634-47. doi: 10.4049/jimmunol.179.3.1634

12. Liu PT, Stenger S, Li H, Wenzel L, Tan BH, Krutzik SR, et al. Toll-like receptor triggering of a vitamin D-mediated human antimicrobial response. Science (2006) 311:1770-3. doi: 10.1126/science.1123933

13. Hansdottir S, Monick MM, Hinde SL, Lovan N, Look DC, Hunninghake GW. Respiratory epithelial cells convert inactive vitamin D to its active form: potential effects on host defense. J Immunol Baltim. (2008) 181:7090-9. doi: 10.4049/jimmunol.181.10.7090

14. Barlow PG, Svoboda P, Mackellar A, Nash AA, York IA, Pohl J, et al. Antiviral activity and increased host defense against influenza infection elicited by the human cathelicidin LL-37. PLOS ONE (2011) 6:e25333. doi: 10.1371/journal.pone.0025333

15. White MR, Tripathi S, Verma A, Kingma P, Takahashi K, Jensenius J, et al. Collectins, $\mathrm{H}$-ficolin and LL-37 reduce influence viral replication in human monocytes and modulate virus-induced cytokine production. Innate Immun. (2017) 23:77-88. doi: 10.1177/1753425916678470

16. Tripathi S, Wang G, White M, Qi L, Taubenberger J, Hartshorn KL. Antiviral activity of the human cathelicidin, LL-37, and derived peptides on seasonal and pandemic influenza A viruses. PLoS ONE (2015) 10:e0124706. doi: 10.1371/journal.pone.0124706

17. Tripathi S, Tecle T, Verma A, Crouch E, White M, Hartshorn KL. The human cathelicidin LL-37 inhibits influenza A viruses through a mechanism distinct from that of surfactant protein D or defensins. J Gen Virol. (2013) 94:40-9. doi: 10.1099/vir.0.045013-0

18. Verjans E-T, Zels S, Luyten W, Landuyt B, Schoofs L. Molecular mechanisms of LL-37-induced receptor activation: an overview. Peptides (2016) 85:16-26. doi: 10.1016/j.peptides.2016.09.002

19. Sly LM, Lopez M, Nauseef WM, Reiner NE. 1,25-Dihydroxyvitamin D3-induced monocyte antimycobacterial activity is regulated by phosphatidylinositol 3-kinase and mediated by the NADPHdependent phagocyte oxidase. J Biol Chem. (2001) 276:35482-93. doi: 10.1074/jbc.M102876200

20. Zheng Y, Niyonsaba F, Ushio H, Nagaoka I, Ikeda S, Okumura K, et al. Cathelicidin LL-37 induces the generation of reactive oxygen species and release of human $\alpha$-defensins from neutrophils. $B r$ J Dermatol. (2007) 157:1124-31. doi: 10.1111/j.1365-2133.2007.08196.x

21. Hansdottir S, Monick MM, Lovan N, Powers L, Gerke A, Hunninghake GW. Vitamin D decreases respiratory syncytial virus induction of NF- kappaBlinked chemokines and cytokines in airway epithelium while maintaining the antiviral state. J Immunol. (2010) 184:965-74. doi: 10.4049/jimmunol.09 02840

22. Di Rosa M, Malaguarnera M, Nicoletti F, Malaguarnera L. Vitamin D3: a helpful immuno-modulator. Immunology (2011) 134:123-39. doi: 10.1111/j.1365-2567.2011.03482.x

23. Cantorna MT, Yu S, Bruce D. The paradoxical effects of vitamin D on type 1 mediated immunity. Mol Aspects Med. (2008) 29:369-75. doi: 10.1016/j.mam.2008.04.004

24. Correale J, Ysrraelit MC, Gaitán MI. Vitamin D-mediated immune regulation in Multiple Sclerosis. J Neurol Sci. (2011) 311:23-31. doi: 10.1016/j.jns.2011.06.027

25. Rosenblatt J, Bissonnette A, Ahmad R, Wu Z, Vasir B, Stevenson K, et al. Immunomodulatory effects of vitamin $\mathrm{D}$ : implications for GVHD. Bone Marrow Transplant. (2010) 45:1463-8. doi: 10.1038/bmt.2009.366
26. Avenell A, Cook JA, MacLennan GS, MacPherson GC. Vitamin D supplementation to prevent infections: a sub-study of a randomised placebo-controlled trial in older people (RECORD trial, ISRCTN 51647438). Age Ageing (2007) 36:574-77. doi: 10.1093/ageing/afm091

27. Urashima M, Segawa T, Okazaki M, Kurihara M, Wada Y, Ida H. Randomized trial of vitamin D supplementation to prevent seasonal influenza A in schoolchildren. Am J Clin Nutr. (2010) 91:1255-60. doi: 10.3945/ajcn.2009.29094

28. Grohskopf LA. Prevention and control of seasonal influenza with vaccines. MMWR Recomm Rep. (2016) 65:1-54. doi: 10.15585/mmwr.rr6505a1

29. Trucchi C, Paganino C, Orsi A, De Florentiis D, Ansaldi F. Influenza vaccination in the elderly: why are the overall benefits still hotly debated? $J$ Prev Med Hyg. (2015) 56:37-43. doi: 10.15167/2421-4248/jpmh2015.56.1.474

30. Goodwin K, Viboud C, Simonsen L. Antibody response to influenza vaccination in the elderly: a quantitative review. Vaccine (2006) 24:1159-69. doi: 10.1016/j.vaccine.2005.08.105

31. Jackson LA. Evidence of bias in estimates of influenza vaccine effectiveness in seniors. Int J Epidemiol. (2005) 35:337-44. doi: 10.1093/ije/dyi274

32. Sundaram ME, Talbot HK, Zhu Y, Griffin MR, Spencer S, Shay DK, et al. Vitamin D is not associated with serologic response to influenza vaccine in adults over 50 years old. Vaccine (2013) 31:2057-61. doi: 10.1016/j.vaccine.2013.02.028

33. Chadha MK, Fakih M, Muindi J, Tian L, Mashtare T, Johnson CS, et al. Effect of 25-hydroxyvitamin D status on serological response to influenza vaccine in prostate cancer patients. Prostate (2011) 71:368-72. doi: 10.1002/pros.21250

34. Kriesel J. Calcitriol (1,25-dihydroxy-vitamin D3) coadministered with influenza vaccine does not enhance humoral immunity in human volunteers. Vaccine (1999) 17:1883-8. doi: 10.1016/S0264-410X(98)00476-9

35. European Medicines Agency. Guideline on Influenza Vaccines - Non-Clinical and Clinical Module. (2014) EMA/CHMP/VWP/457259/2014

36. Zhang X, He Y, Ding M. Simultaneous determination of tryptophan and kynurenine in plasma samples of children patients with Kawasaki disease by high-performance liquid chromatography with programmed wavelength ultraviolet detection. J Chromatogr B Analyt Technol Biomed Life Sci. (2009) 877:1678-82. doi: 10.1016/j.jchromb.2009.04.013

37. Farges M-C, Minet-Quinard R, Walrand S, Thivat E, Ribalta J, WinklhoferRoob B, et al. Immune status is more affected by age than by carotenoid depletion-repletion in healthy human subjects. Br J Nutr. (2012) 108:2054-65. doi: 10.1017/S0007114512000177

38. Schleck M-L, Souberbielle J-C, Jandrain B, Da Silva S, De Niet S, Vanderbist F, et al. A randomized, double-blind, parallel study to evaluate the dose-response of three different vitamin D treatment schemes on the 25-hydroxyvitamin D serum concentration in patients with vitamin D deficiency. Nutrients (2015) 7:5413-22. doi: 10.3390/nu7075227

39. Heaney RP, Davies KM, Chen TC, Holick MF, Barger-Lux MJ. Human serum 25-hydroxycholecalciferol response to extended oral dosing with cholecalciferol. Am J Clin Nutr. (2003) 77:204-210. doi: 10.1093/ajcn/77.1.204

40. Wang G, Mishra B, Epand RF, Epand RM. High-quality 3D structures shine light on antibacterial, anti-biofilm and antiviral activities of human cathelicidin LL-37 and its fragments. Biochim Biophys Acta (2014) 1838:216072. doi: 10.1016/j.bbamem.2014.01.016

41. Yang Y-M, Guo Y-F, Zhang H-S, Sun T-Y. Antimicrobial peptide LL37 circulating levels in chronic obstructive pulmonary disease patients with high risk of frequent exacerbations. J Thorac Dis. (2015) 7:740-5. doi: 10.3978/j.issn.2072-1439.2015.04.33

42. Bhan I, Camargo CA, Wenger J, Ricciardi C, Ye J, Borregaard $\mathrm{N}$, et al. Circulating levels of 25-hydroxyvitamin $\mathrm{D}$ and human cathelicidin in healthy adults. J Allergy Clin Immunol. (2011) 127:1302-4. doi: 10.1016/j.jaci.2010.12.1097

43. Dixon BM, Barker T, McKinnon T, Cuomo J, Frei B, Borregaard N, et al. Positive correlation between circulating cathelicidin antimicrobial peptide (hCAP18/LL-37) and 25-hydroxyvitamin D levels in healthy adults. BMC Res Notes (2012) 5:575. doi: 10.1186/1756-0500-5-575

44. Alvarez JA, Zughaier SM, Law J, Hao L, Wasse H, Ziegler TR, et al. Effects of high-dose cholecalciferol on serum markers of inflammation and immunity in patients with early chronic kidney disease. Eur J Clin Nutr. (2013) 67:264-9. doi: $10.1038 /$ ejen.2012.217 
45. Hata TR, Audish D, Kotol P, Coda A, Kabigting F, Miller J, et al. A randomized controlled double-blind investigation of the effects of vitamin D dietary supplementation in subjects with atopic dermatitis. J Eur Acad Dermatol Venereol. (2014) 28:781-9. doi: 10.1111/jdv.12176

46. Sharifi A, Hosseinzadeh-Attar M, Vahedi H, Nedjat S. A randomized controlled trial on the effect of vitamin D3 on inflammation and cathelicidin gene expression in ulcerative colitis patients. Saudi J Gastroenterol. (2016) 22:316-23. doi: 10.4103/1319-3767.187606

47. Principi N, Marchisio P, Terranova L, Zampiero A, Baggi E, Daleno $\mathrm{C}$, et al. Impact of vitamin $\mathrm{D}$ administration on immunogenicity of trivalent inactivated influenza vaccine in previously unvaccinated children. Hum Vaccines Immunother. (2013) 9:969-74. doi: 10.4161/hv. 23540

48. Hirota Y, Kaji M, Ide S, Goto S, Oka T. The hemagglutination inhibition antibody responses to an inactivated influenza vaccine among healthy adults: with special reference to the prevaccination antibody and its interaction with age. Vaccine (1996) 14:1597-602.

49. McElhaney JE. Nutrition, exercise, and influenza vaccination. J Gerontol A Biol Sci Med Sci. (2002) 57:555-6. doi: 10.1093/gerona/57.9.M555

50. Hara M, Tanaka K, Hirota Y. Immune response to influenza vaccine in healthy adults and the elderly: association with nutritional status. Vaccine (2005) 23:1457-63. doi: 10.1016/j.vaccine.2004.09.022

51. Laird E, McNulty H, Ward M, Hoey L, McSorley E, Wallace JMW, et al. Vitamin D deficiency is associated with inflammation in older Irish adults. J Clin Endocrinol Metab. (2014) 99:1807-15. doi: 10.1210/jc.2013-3507

52. Penna G, Amuchastegui S, Giarratana N, Daniel KC, Vulcano M, Sozzani S, et al. 1,25-Dihydroxyvitamin D3 Selectively modulates tolerogenic properties in myeloid but not plasmacytoid dendritic cells. J Immunol. (2007) 178:14553. doi: 10.4049/jimmunol.178.1.145

53. Hong E-G, Ko HJ, Cho Y-R, Kim H-J, Ma Z, Yu TY, et al. Interleukin10 prevents diet-induced insulin resistance by attenuating macrophage and cytokine response in skeletal muscle. Diabetes (2009) 58:2525-35. doi: $10.2337 / \mathrm{db} 08-1261$
54. Lu C-H, Allen K, Oei F, Leoni E, Kuhle J, Tree T, et al. Systemic inflammatory response and neuromuscular involvement in amyotrophic lateral sclerosis. Neurol Neuroimmunol Neuroinflamm. (2016) 3:e244. doi: 10.1212/NXI.0000000000000244

55. Carlson CM, Turpin EA, Moser LA, O’Brien KB, Cline TD, Jones JC, et al. Transforming Growth Factor- $\beta$ : activation by neuraminidase and role in highly pathogenic $\mathrm{H} 5 \mathrm{~N} 1$ influenza pathogenesis. PLoS Pathog (2010) 6:e1001136. doi: 10.1371/journal.ppat. 1001136

56. Frumento G, Rotondo R, Tonetti M, Damonte G, Benatti U, Ferrara GB. Tryptophan-derived catabolites are responsible for inhibition of $\mathrm{T}$ and natural killer cell proliferation induced by indoleamine 2,3-dioxygenase. J Exp Med. (2002) 196:459-68. doi: 10.1084/jem.20020121

57. Mellor AL, Lemos $\mathrm{H}$, Huang L. Indoleamine 2,3-Dioxygenase and tolerance: where are we now? Front Immunol. (2017) 8:1360. doi: 10.3389/fimmu.2017.01360

58. Yang C-S, Shin D-M, Kim K-H, Lee Z-W, Lee C-H, Park SG, et al. NADPH oxidase 2 interaction with TLR2 is required for efficient innate immune responses to mycobacteria via cathelicidin expression. J Immunol. (2009) 182:3696-705. doi: 10.4049/jimmunol.0802217

Conflict of Interest Statement: The authors declare that the research was conducted in the absence of any commercial or financial relationships that could be construed as a potential conflict of interest.

Copyright (C) 2019 Goncalves-Mendes, Talvas, Dualé, Guttmann, Corbin, Marceau, Sapin, Brachet, Evrard, Laurichesse and Vasson. This is an open-access article distributed under the terms of the Creative Commons Attribution License (CC BY). The use, distribution or reproduction in other forums is permitted, provided the original author(s) and the copyright owner(s) are credited and that the original publication in this journal is cited, in accordance with accepted academic practice. No use, distribution or reproduction is permitted which does not comply with these terms. 